Dr ALLISON OOSTERMAN is a senior lecturer in journalism at Auckland University of Technology.

\section{Everybody's uncle}

Scrim - the man with a mike, by William Renwick. Wellington: Victoria University Press, 2011, 308 pp. ISBN 978-0864736956

$\mathrm{B}$ IOGRAPHY is currently one of the most popular literary genres but New Zealand writers seem to choose their subjects from quite a narrow range of sportsmen and military figures. Few have chosen to write about historic media individuals. The last one I recall was Facing the Music: Charles Baeyertz and the Triad, by Joanna Woods (2008).

So when an author does write a book about one of the country's leading broadcasters, Colin Scrimgeour, as William Renwick has done, it is impossible not to praise him for doing so, although his is not the first. Les Edwards (1971), a journalist and Labour supporter, had previously written Scrim:Radio rebel in retrospect. Renwick alludes to this earlier book but claims Edwards was 'skilful' as an advocate for the Labour Party and its policies but 'economical with the facts' (p. 240).

Renwick sets out to put the

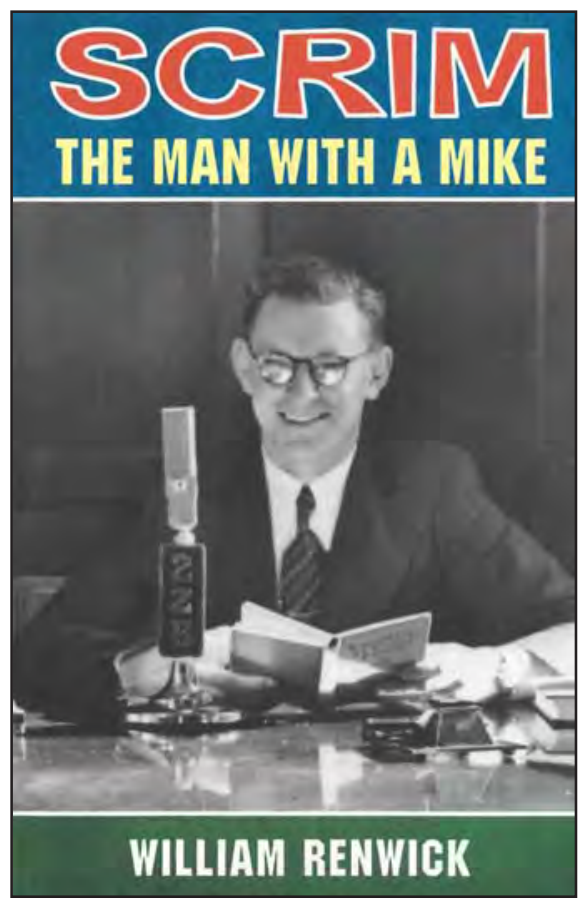

record straight on some of the myths surrounding this controversial broadcaster, a Methodist minister, whose Friendly Road sessions on private radio $1 \mathrm{ZR}$ in the 1930 s made him one of the most popular men in the country. In the time of depression he brought hope and comfort to many and in so doing attracted thousands to any gathering he attended.

Worried about his influence regarding its commercial radio broadcasting policy, the Coalition government of the day jammed his planned radio session just before the 1935 election. Labour was swept into 
power and Scrimgeour's years of agitation for recognition of commercial broadcasting came to fruition when he was made head of the commercial service in 1936.

Nigel Hamilton (2008) says the life story is biography's 'most prized possession' (p. 100) and in this respect the story of Colin Scrimgeour as told by William Renwick does follow the Shakespearean 'seven ages of man' from birth to death.Renwick has had a wealth of material to call upon, not the least being the four-part account by Scrimgeour's friend Harry Bell (1934), but also a cornucopia of documents held originally by the Broadcasting History Trust and now in the Alexander Turnbull Library.

Broadcasting historians have been well served with the archived material available to them, and this is shown in the plethora of books published on New Zealand broadcasting. As a press historian I look on in envy, and continue to bemoan the lack of interest in finding and preserving our newspaper past. Renwick has certainly made good use of his sources and scoured them for every last titbit of information about Scrimgeour. While this is laudable, it is also important to know when to leave material out. There are fragments of Scrimgeour's life which have been included which hang suspended outside the general narrative and which could well have been excluded.

Renwick charts Scrimgeour's rise to be the head of the commercial broadcasting service and then his dismissal by Peter Fraser in 1943. He follows Scrimgeour to Australia and back again to see him flirting with television as a medium. Then the reader is drawn into the creation of The Scrim-Lee Papers, a collaboration between Scrimgeour, socialist politician, John A Lee, and writer Tony Simpson (1976).

It's probably hard for those who have always known television to realise just how important radio was when Scrimgeour hit the airwaves and became a household name. Those of a certain age, I'm sure, can remember the time spent around the radio listening to Portia Faces Life, Dr Paul, It's in the Bag or The Archers. Those even older may recall Uncle Scrim and his Fellowship of the Friendly Road. My dear friend and mentor, Phillida Dive, now 92, and sister-in-law of A. R. D. Fairburn, can attest to the power of radio in the lives of New Zealanders in those early years.

'We lived by listening to radio, it was extremely important,' she says. 'It was the beginning of stars, like Kenneth Melvin who was "Tusitala, teller of tales", Jocelyn de Jocelyn, Marina and people like Uncle Scrim.' While 
she didn't listen much to Scrimgeour, she says she was well aware of what a controversial figure he was, and how skilled he was at holding his radio audience. My father, a conservative farmer from Waitoa in the Piako, got his pilot's licence at the same time as Scrimgeour, but had no truck with him, scorning his socialist principles, and wouldn't have been caught dead listening to his programme.

John Garraty (1957) says biographers must not deal only with the facts of his subject's career-what he did, why he did it and how he influenced his times and was in turn affected by them, but he must also describe the man himself - his personality and character, his individuality (p. 23). In the first respect, Renwick has done a masterful and thorough job, but insofar as the second part of Garraty's admonition, I am not so convinced. I am still uncertain what this man was like, as a man.

I garnered no sense of Scrimgeour as a husband, as a father, as a son. There is little sense of the domestic or the personal in this book. Lenna, his first wife, (spelled Lena in the book, with no explanation, when the birth certificate clearly says Lenna) gets one page, (p. 42), and she is not indexed, as his second wife, Pam, is not. It is mentioned in passing that Scrimgeour had children. Where or when they were born and what their names were we do not learn, until one is mentioned at the end of the book.

This may be a small gripe but as biographer Leon Edel (1986) says: 'The most difficult task of the biographer is the search for the figure under the carpet, the evidence in the reverse of the tapestry, the life-myth of a given mask' (p. 24). The private life of an individual reveals aspects of his character that may not be visible in his public life.

Another minor issue concerns the indexing, which is not as thorough as it could be and annoying when one is trying to fix incidents and people in one's head as one reads. The author also has the habit of dropping names into the story without identifying the people first. Many readers will not know some of the names mentioned, but the explanation often never comes, or it comes on following pages.

Stephen Oates (1986) says there are three types of biography-pure or literary biography, where the author narrates a life story that engages the heart and the mind; a critical study, where the author 'analyses with appropriate detachment and scepticism' and a scholarly chronicle which is a straightforward recounting of facts, where the narrative voice tends to be dry and detached but informative (p. ix). Renwick's book, I believe, falls into this latter category. 


\section{References}

Bell, H. (1934). Hello everybody: Life is a friendly road. Auckland: Unity Press.

Edel, L. (1986). In S. B. Oates, Biography as high art: Life writers speak on their art. Amherst: University of Massachusetts Press.

Edwards, L. (1971). Scrim: Radio rebel in retrospect. Auckland: Hodder and Stoughton.

Hamilton, N. (2008). How to do biography: A primer. Cambridge, Mass.: Harvard University Press.

Garraty, J. A. (1957). The nature of biography.London: Jonathan Cape.

Oates, S. B. (1986). Biography as high art: Life writers speak on their art. Amherst: University of Massachusetts Press.

Scrimgeour, C. G., Lee, J. A. and Simpson, T., (1976). The Scrim-Lee papers: C. G. Scrimgeour and John A. Lee remember the crisis years 1930-40. Wellington: A. H. \& A. W. Reed.

Woods, J. (2008). Facing the music: Charles Baeyertz and the triad. Dunedin: Otago University Press.

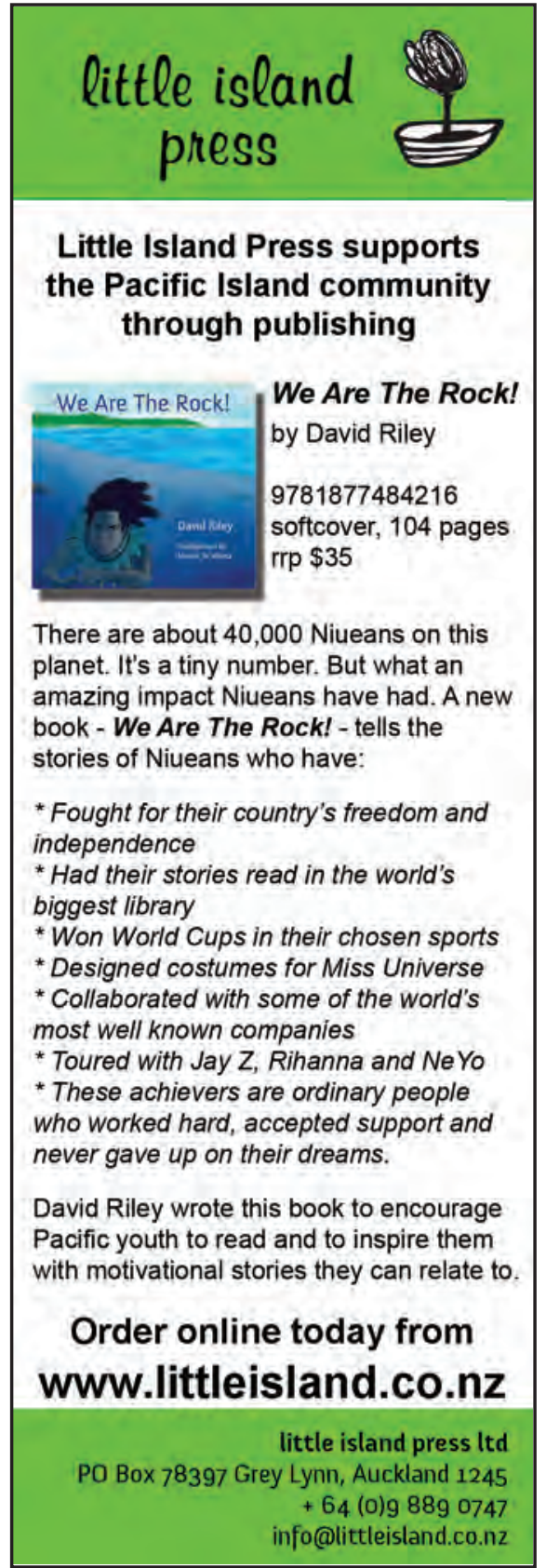

